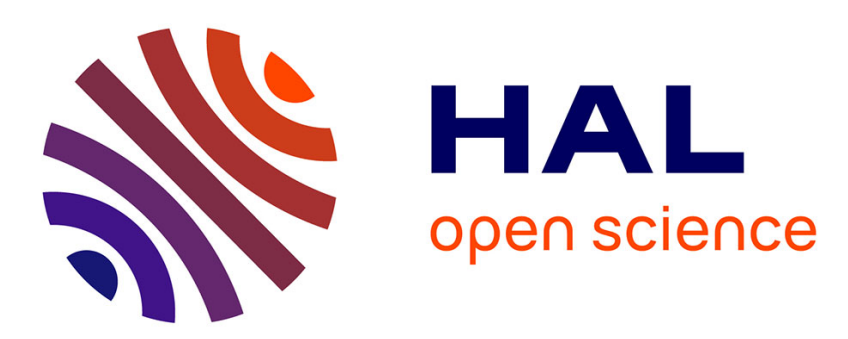

\title{
Juggling with Moving Sexual Norms: Senegalese Women's Attempts to Make Their Way Through Migration
}

\author{
Melissa Blanchard
}

\section{- To cite this version:}

Melissa Blanchard. Juggling with Moving Sexual Norms: Senegalese Women's Attempts to Make Their Way Through Migration. Migration Letters, 2019, Sexuality and Migration, 16 (4), pp.481-490. 10.33182/ml.v16i4.794 . hal-02365061

\section{HAL Id: hal-02365061 https://hal.science/hal-02365061}

Submitted on 15 Nov 2019

HAL is a multi-disciplinary open access archive for the deposit and dissemination of scientific research documents, whether they are published or not. The documents may come from teaching and research institutions in France or abroad, or from public or private research centers.
L'archive ouverte pluridisciplinaire HAL, est destinée au dépôt et à la diffusion de documents scientifiques de niveau recherche, publiés ou non, émanant des établissements d'enseignement et de recherche français ou étrangers, des laboratoires publics ou privés. 


\title{
Juggling with Moving Sexual Norms: Senegalese Women's Attempts to Make Their Way Through Migration
}

\author{
Melissa Blanchard ${ }^{1}$
}

\begin{abstract}
Women's sexual behaviour is the mirror of larger social dynamics that cross-cut migration and the crux where individual agency and social constraints come face to face. This article examines how, among Senegalese migrants in Marseille, the representations of feminine sexual conduct have varied over time, reflecting changes in the community's social composition and in the religious layout of the city. On the other hand, it shows that women's representations of marital and non-marital sex vary enormously according to their education, caste, geographic origin and age, influencing the different ways they juggle with changing social norms in order to make their way through migration.
\end{abstract}

Keywords: Senegalese migrants; women; sexual behaviour; social control; Marseille.

\section{Introduction}

Although in Senegal migration is considered as one of the best sources of income and social promotion people may aspire to (Riccio 2005, Fouquet 2007b), a persistent narrative depicts feminine migration as a potential danger, entailing the loss of decent women for the community. It implies women will experiment with new opportunities and embrace the loose sexual behaviour of the West, especially if they move a secular and licentious France. In Marseille, which has been the destination of African migration since the early 1920s, a highly puritan Senegalese community advocates for even stricter feminine sexual behaviour than in Senegal and non-marital sex becomes the hotspot where all fantasies and control paranoia converge. Both men and women participate in promoting new restrictive norms for women's sexuality, a product of migration, yet said to be ancestral. Nevertheless, things haven't always been like this. Senegalese migrant women have experienced certain sexual freedom in the past without incurring in negative social consequences.

This article will address the ways in which the representations of Senegalese women's sexual behaviour have varied over time, reflecting the evolution of the community's social composition in Marseille and religious layout of the city, as puritan Islam progressively gained importance. Migrant women's sexual practices mirror these changes, as they are an attempt to negotiate between different intensities of community control and individual existential paths. Even though several researchers have stated that migration may be a social field enhancing migrant women agency (Pedraza 1991, Quiminal 2000, Schmoll 2005), this paper will show that the opposite may be true, too. Senegalese migrant women may experience a restriction of their sexual liberty due to Marseille's particular social structure and their migration timing.

\footnotetext{
${ }^{1}$ Melissa Blanchard, Centre Norbert Elias, EHESS Marseille, La Vieille Charité, 2, rue de la Charité, 13002 Marseille, France. E-mail: blanchard.melissa@gmail.com.
} 
The paper will first situate the repressive discourse of female sexuality in Senegal in a broader context (1). It will then present women's different sexual behaviours, putting them in relation to their migrant career in Marseille. (2). The conclusion will discuss how changes in the social configuration of the migrant community produce changes in the type of sexual relations that are socially acceptable and how the different ways women juggle with these norms are influenced by the elements determining their social status.

\section{The Senegalese patriarchal family and narratives on women's sexual behaviour}

There's a panoply of erotic accessories for women, in Senegal. Small loincloths (bethio) worn as panties under which women are naked - some of them look like a fishnet made of beads, others may have drawings of sexual positions and obscene phrases written on them (gor ak djiguène); home-made exciting incense (thiouraye); waist bead-strings which bang together when women make love (bin-bin); clothes-padding making bottoms and thighs look well-rounded; bed sheets with pornographic illustrations; undergarments made of bead strings, and so on. All this paraphernalia is well known in Senegal and, except for sexual loincloths, all the items are shown and openly sold in city markets. Though, as paradoxical as it may seem, Senegal is a very puritan society: sex is something you cannot speak about publicly. These props are reserved to married women and used inside what I call "the sacred ring of marriage", since sexually satisfying their husband is one of women's principal role. This gains even more importance in the context of permanent wives' competition inside polygynous marriages (Fainzang and Journet 1988). Yet, nonmarital sex in Senegal is not an exception (Hannaford and Foley 2015), even if women publicly deny it. Besides, one of the fundamental duties of a good husband is to sexually satisfy his wife, ${ }^{2}$ in addition to provide for her (Babou 2008). Nonetheless, this does not imply a woman is free to look for her satisfaction: she must restrict herself to the marriage perimeter. Islam, and specifically the West-African kinship ideology, attaches great importance to the regulation of women's sexuality.

Extensive anthropology scholarship links social control over women's sexual behaviour to the universal need to control the biological and symbolic reproduction of society (Lévi-Strauss 1949, Héritier 1996). This literature and that on the construction of sexual desire and sexual practices (Foucault 1976, Balandier 1984, Rubin 1984) shows that sexuality, which we are keen to consider as one of the most individual fields of human action, is indeed one of the most socially controlled and oriented.

Traditionally, in West African patriarchal societies women procreative potential is a sort of "currency of exchange" between families. Women are exchanged through marriage, the institution that rules to whose social group children belong (Meillassoux 1975). These transactions are managed by the eldest men of the family who, in order to maintain his negotiating capacity, must ensure that girls in their community are available for the exchange, i.e. virgins (Coquery-Vidrovitch 1994). In many rural societies, the entire community monitors women's sexual behaviour (Mathieu 1985). In contemporary urban and neo-liberal West African settings, this representation is still central to the social meaning of marriage.

According to anthropologist Paola Tabet, marriage supports the ideological enslavement of female sexuality to reproduction (Tabet 1985). It's a social institution exposing women to greater risk of pregnancy, providing generic coverage of all fertilization opportunities. Women enter

\footnotetext{
${ }^{2}$ This is consistent with Islamic and Wolof values and is clearly written in the Code de la Famille, the civil document that governs familial rights in Senegal. If a husband fails in this responsibility a woman can ask for a divorce.
} 
marriage and are kept in it by a set of psychological and physical constraints, which train them into reproductive sexuality, obligate them to conjugal duty and submit them to the male sexual desire. Dividing women into two categories is the foundation of this ideology: one dedicated to reproductive sexuality (wives), the other to sexual pleasure (whores). If a woman independently takes control over her body and her sexuality, then, in West-African societies such as Senegal, she undergoes the stigma of femme libre, free woman, an expression people consider equivalent to whore (Blanchard 2012). Tabet stresses that sexual-economic exchanges form a continuum: marriage on one end and prostitution on the other. Prostitution is not defined by a specific content but by a relationship through which a woman breaks the rules of masculine ownership over her body and her sexuality, managing them independently (Tabet 2004). Disapproving prostitution becomes, therefore, a discourse on the forms of property and on the legitimate use of women's bodies, which expresses the rights women have over their body, and those others have (husband, father, kinship group). Women who do not comply with the social rules of sexual management are considered a menace for the established order and are marginalized.

Yet, aside from marriage and prostitution, there are other practices implying an economicsexual exchange in Senegal. Traditionally, when a young woman enters the "marriage market" (in her late teens and early twenties) she is usually courted by several men. They have to compete and to display their interest in offering her and her parents' gifts and money. The timing between courting practices, affection exchange and sex in return is brief. If a woman begins entertaining multiple relations at the same time, with what she might consider friends or boy-friends, without them (supposedly) knowing about each other, in Wolof they'll say she is mbaraan (Fouquet 2007a). Having multiple sexual partners supporting her with gifts or financial aid, besides giving her affection, can be a source of autonomy for a woman in transitional phases (before marriage or between two marriages for young widows or divorcees) or a "complement" to unsatisfying marriages, allowing women to seek love, sex and financial resources with other partners (Hannaford and Foley 2015). There is a sort of continuum between these practices and a mbaraan partner may become a husband. The important thing for a woman is to conceal she is having multiple partners, or at least to display ambiguity regarding it, as to preserve her social status. Mbaraans are socially condemned but can be tolerated as long as the ambiguity over a woman's relations persists.

For some women, emigration may be an escape strategy from the gender oppression the marriage system and the condemnation of mbaraan implies (Blanchard 2007). It has been stressed that women emigration, as an active response to a situation of exploitation, may even be considered as a struggle (Morokvasic 1983). But if some women left Senegal and came to Marseille looking for empowerment, they didn't necessarily find it when it comes to sexual life. As the accounts will show, in the context of Marseille such fluidity among the different practices disappeared over time, as the migrant community became stricter in tolerating and controlling women's sexual behavior and fostering a representation of women's sexuality limited to marriage.

\section{Continuities and breaks in women's sexual behaviour}

Migration is a process where social norms that were determinant in migrants' original countries meet and merge with other norms. If this may bring a loosening of previous social rules, the opposite may also occur, with migrant communities strengthening a more conservative view of the original norms. As evidence from the field shows, these movements may coexist in the same migrant community and evolve over time in response to changes in the receiving context. The accounts I analyze are drawn from ethnographic fieldwork I carried out with Senegalese women in Marseille during my PhD (2004-2008) and continued years later (2013-2016). During this reiterated 


\section{Juggling with Moving Sexual Norms}

fieldwork, I collected thirty-nine ${ }^{3}$ life histories of Senegalese women working in trade, in French and in basic Wolof. ${ }^{4}$ Interviews were coupled with long-term observation of professional, social and family activities. The time allowed for establishing personal relationships and my researcher status just faded in the background, which granted me access to intimate discourses and spaces.

The accounts I present draw different representations of sexual relations. They tackle the consequences of changes in the social composition of the migrant community had on the social norms regulating women's sexuality. They also show the different ways women choose to juggle with these norms, according to the elements determining their social statuses, such as age, caste, ${ }^{5}$ education, geographic origin and life course.

\section{Sex as a support for life and business in migration}

75 years old Awa receives me in a ravaged room she rents from an Algerian man in downtown Marseille. She greets me bare-chested, her hair uncovered (against Islamic law), a loincloth around her waist and smoking a pipe. An elderly Senegalese man is in the room helping her fill out the form for a money transfer for her family: she is illiterate and barely speaks French. No one seems shocked she's got her breasts uncovered. When men go away, Awa tells me her story. She comes from a griot family, the lowest level of the Senegalese system of castes. Griots are jesters and praise singers. This status gives them freedom of speech: they are the only ones allowed to freely speak about sex and to mime it in dances in order to entertain. She left her native region, in rural Senegal, to go and live in Northern France with her husband. When he retired, in the late 70s, she decided to stay in France alone, head South towards Marseille and trade. She's very proud to be able to help her family at home; she had a house built for her daughters in the suburbs of Dakar and she helps sisters living in the countryside. In Marseille, she's a stallholder in the city markets, but in the past she also rented containers in cargo ships she filled with second-hand domestic electrical supplies, linen, clothes and sometimes cars. One of her daughters picked the merchandise in Dakar and sold it around Senegal.

How comes she had the money to organize such a business? She did it through mbaraan: having multiple sexual partners who gave her money and gifts.

"One will pay the rent, in return you make him soup, so when in the evening he comes back from work he finds a Senegalese meal. If the other gives you money, he's entitled to

\footnotetext{
${ }^{3}$ Statistical data referring to people's origin living in a specific area are not available in France, since the government explicitly wants to avoid " ethnic statistic ». Coupling my observations with the information I collected from consular sources and migrants, I estimated that in 2008 around 1000 Senegalese migrants were present in Marseille, 100 of whom were women.

${ }^{4}$ Wolof is the Senegalese common language.

5 "Castes" characterize much of West African society. A minimal definition of West-African castes is that of hereditary, endogamous groups, linked to a professional specialization and hierarchized. The Wolof people are divided between non-artisans, often farmers (géér) and craftsmen (nyényo), and these are divided into different professional groups (Diop 1981). At the bottom of the caste hierarchy are the griots (géwel), sorts of jesters and praise singers. Castes have no relevance in everyday urban life, but the hierarchical relations are reactivated in marriages and in family ceremonies, where géér distribute money to the nyényo family that traditionally are their dependents. Castes are endogamous and while different groups of nyényo may inter-marry, géér families are usually opposed to one of theirs marrying a nyényo, as it would correspond to marrying down. Géér-nyényo marriages might exist, but usually they are ill considered from the géér partner's family. The same situation is repeated in Marseille among first and second generation migrants, who preferentially marry inside their social level. Marrying someone of different ethnic origin, including a European partner, would be socially more acceptable than marrying down. Families have different practices according to the importance they attach to traditional marriages, however, in general marrying with a Muslim partner is considered better than marrying a partner of another religion. This is why, even if young people often seek a "White" partner for the wealth and social status he/she might offer, their family may not consider it as a desirable marriage. A sexual stratification, orientating young people choices, may thus be drawn as it follows: White partners/géér partners are the most valuable and then other African partners if they are rich, nyényo partners (and among them, those who are rich). This stratification may not coincide with their parents' though, as they would usually prefer a géér partner, other Muslim African partners, and nyényo partners.
} 
affection..." (Awa).

Having several mbaraan relationships can be an accumulation strategy, helping women make their way through migration and trade. A bond with a merchant, moreover, may provide access to wider trade networks, or become a chance for economic partnerships. In mbaraan, economic, sexual and emotional exchanges are closely intertwined and it is difficult to discern which is prevalent, as is the case of any emotional-sexual relationship between men and women, including marriage, in Senegalese society (Diop 1985). Indeed, male interest - a suitor, a lover, a husband - is always measured against the extent to which he satisfies a woman's material needs. There is a clear connection between the gifts in exchange for sexual relations and the value of the woman receiving it (Hannaford and Foley 2015). But engaging in sexual relations outside marriage exposes women to the negative stigma of free women. For Awa that wasn't a problem in the past, as in the 80s there was still a consistent community of Senegalese sailors, dockers and demobilized tirailleurs sénégalais ${ }^{6}$ who enjoyed sexual relations, affective and economic partnerships with free women. Moreover, the money she sent home, led the family close an eye on the way she earned it. Suspicions over her sexual activities were wiped away by her capacity to broadly redistribute her fortune in her family circles. But in recent years, she noticed that no other Senegalese woman came to see her and she began to feel isolated. With the increase of family reunions in the 90s, lots of decent wives arrived in town and, at the same time, the powerful Murid ${ }^{7}$ community of Marseille oriented towards a more puritan morality. This brought to a revision of what was to be accepted and what was to be forbidden in the migrant community ${ }^{8}$ regarding women's sexual behaviour. Indeed, at present Awa is known as being a free woman and other women, respectable wives and mothers, avoid her, fearing they will lose their good reputation if they visit her.

\section{No-Sex as an embodied social censorship that expands in migration}

Caste origin, family background and education heavily influence the decisions women make about their sexuality and may push some to avoid relations with men, in order not to be assimilated to a free woman. Diattou is 40 years old; a social worker in her housing estate, she is educated and comes from the upper rank of the caste system, that of free people or nobles (géer), a social group whose behaviour must show dignity, honour and elegance (Diop 1981). Diattou originally lived in a coastal town in Senegal, Mbour, and arrived in France in the 90s as a second wife, to follow her husband, from whom she is now separated. She explains:

"I had no freedom neither in my original family nor in my marriage. It's strange, but even if now that I am divorced I could do it, I am not living my freedom. My mother is dead, I've got the keys of my own apartment and no one is monitoring me, I could do whatever I want, but... I cannot go out with men. It's because of gossip in the community. What others may say about me is very important to me... You see, in Senegal, we don't have excisions, only minorities do it, but a woman hasn't got the right to follow her instincts, her pleasure. When they raise you they teach you that you are a whore if you sleep with someone outside marriage. A French friend told me that renouncing sex is like giving up a big part of happiness, but in our culture a woman is not allowed to find her pleasure with a man, even inside marriage. The man is the

\footnotetext{
${ }^{6}$ Colonial soldiers of the French Army coming from West-Africa, who served in the First and Second World War.

${ }^{7}$ Murids are one of the most important brotherhoods of Senegalese Islam (Schmidt di Friedberg 1994, Babou 2002, Buggenhagen 2009) and are particularly influential in migration and trade (Ebin 1993, Bava 2003a, Riccio 2004).

${ }^{8}$ The Senegalese migrant community in Marseille is composed by people who frequent each others assiduously through sociability circles, religious meetings and family celebrations.
} 


\section{Juggling with Moving Sexual Norms}

one who's got to take his pleasure with his wife, who does what he wants. If a woman sleeps with men outside the marriage, just for pleasure or for money, she is a free woman. Free woman and whore, it's the same thing to me".

Diattou expresses the need to fulfil the role of a decent woman such as a conservative community advocates. She autonomously decides to confine herself to the perimeter of licit behaviour, showing she embodied the social constraints over women's sexuality. Such a situation seems to grow stronger in migration, as the migrant community broadly uses gossip to sanction deviant behaviour. Consequently, life in emigration could place more constraints if compared to life in the country of origin as there the family's (high) social status could vouch for her behaviour. As Diattou explains:

"Here there are a lot of bad-mouthing, jealousies, it's worse than in Senegal. Because down there, people know who you are, where you live, everyone knows everyone. People respect each other. On the contrary, here, no one really knows you, they do not know where you come from. Everyone is on the same level: we're all immigrants. Lots of people are illiterate and it's very hard, it's a harsh world".

\section{Migration as an experience fostering pleasure sex limited to the sacred ring of marriage}

If in emigration women want to maintain a decent social status, they cannot seek pleasure outside of the marriage. Yet, migration can also be an existential experience affecting the way sex is conceived within marriage. Fatou, 35 years old, left Senegal and joined her parents in France in her teens. In Marseille, at the age of 19, she married a cousin (same griots caste) her parents chose for her, who came from Senegal through family reunion after marriage. Initially, she found sexual relations unsatisfying. She had no pleasure, she feared intercourse and, furthermore, the couple had no children. As a child, Fatou had been abused by a man of her family, but she didn't dare say anything because she feared adults would say she was responsible for arousing him. She never had a sexual relationship since. One day, when already married in Marseille, she heard on TV that a connection could be made between abuse and difficulties in sexual relations and that the latter could be treated. Stepping out of her "subordinate wife" role, Fatou proposed to her husband to go and see a sexologist together. Her husband accepted and followed the therapist's tips. It worked out and intercourse became pleasant. Fatou is now a mother of five.

Her view of intimate relations in a marriage is completely different than Diattou's thanks to her family griot background, the upbringing in France and the open talk about sex between a husband and wife. In Marseille, she attended junior college where she compared herself with other teens; back then, as a young adult, she dreamed of a mutually satisfying marriage. As a consequence, intimacy encompasses the possibility of talking about sex and of imagining shared solutions, including speaking of sexuality in front of a stranger (the sex-therapist), which might question the male virility. Equality is also reflected in the couple's professional situation: Fatou began working as a stallholder soon after her second child was born gaining visibility in the city's trade milieu. Her husband joined her on the market stall some years later. He helped to load and unload the merchandise while selling his own goods in a separate part of the stall.

This is not to say that migration equals sexual liberation. As a teenager Fatou knew that if her parents knew she had a (French) boyfriend, they would "kill her" - that is, beat her with a belt. She couldn't have the same sexual experiences her classmates had. Sexuality, in her family, is accepted only within the "sacred ring" of marriage. 


\section{A trampoline for migration}

Another way women may choose to avoid being stigmatized in their social community because of their sexual behaviour is to step out of it thanks to a marriage with a toubab (a white man), which is at the same time a strategic choice allowing them to migrate. Migration can thus be considered a further step in the individualization process, in the sense of emancipation from social constraints (Marie 1997), women undertook with mbaraan relationships. For Sokhna, 34, openly talking of sex and assuming a controversial sexual behaviour was a way to cut ties with her original family and community, before diving into migration. A tegg born in Dakar, Sokhna finished her schooling at the age of 14, met a Frenchman serving as a soldier in Senegal when she was 25, married him and left the country. At present, she works as an Internet underwear retailer. When she was still in Senegal, her parents opposed the marriage but Sokhna didn't comply with the interdiction. She felt she owed them nothing, since they abandoned her as a child, "lending" her to her grandmother," even though she begged them to take her with them. When her mother told her she was betraying her family with this marriage, she couldn't restrain herself and exploded:

"You cannot decide what I must do or not do. You abandoned me and now you've got to let me live my life! And just so you know, I am not a virgin anymore, in any way. I have already been broken in the front and in the back!"

Her mother remained speechless and never tried to stop her plans again, feeling she lost a daughter. A fracture was drawn with these outrageous words. Sokhna knew that talking openly about sex would have been a point of no return, but she found she had suffered enough and didn't care about her mother's opinions. Thanks to this confrontation she knew she was leaving Senegal to live her life in France.

Sokhna uses all the Senegalese seduction arts in order to keep her husband physically interested in her. Seduction and sex appeal were palpable in her domestic space. When she received me she wore a bethio through which I could see her bottom and the bin-bins and a see-thru tunic, which left her breasts visible. Migration is both social emancipation from her family and personal fulfilment, as she can live an emotional, sexual and professional life according to her own preferences. Sokhna, indeed, openly criticized Senegalese representations of female sexuality, the social obsession with virginity and the way Senegalese men conceive sex ("only to take their pleasure. To relieve themselves. They do not care if the girl doesn't feel any"). Contrary to Diattou, she thinks that

"you can talk about everything, on the pillow. You can tell a man what you like or do not like when you make love. You can train him".

Sokhna is free because she decided to break the social convenience rules and to step out from a community and a family who already condemned her.

\section{Conclusion: migration and changes in women's sexual life}

The fieldwork I carried out in Marseille lead me to reflect on three major points regarding the links between migration and the changes in Senegalese female sexual behaviour.

First: representations of non-marital sex in the Senegalese migrant community varied over time and generations. Senegalese immigration in Marseille began with the arrival of men migrating alone, as soldiers and sailors during the First World War (Bertoncello 2000). Until the 80s, among African migrants, Marseille was known as a port where (formal and informal) international trade

\footnotetext{
${ }^{9}$ It's current practice, in Senegal, to leave a child with a family member who hasn't got any or hasn't got anyone to live with.
} 


\section{Juggling with Moving Sexual Norms}

and sex work were among the dominant activities (Bertoncello and Bredeloup 2004). This went along with West-African practices of free women. But then two factors contributed to changing the social landscape: firstly, family reunions augmented control over women's behaviour finding justification in rediscovered ancestral social norms. Secondly, the Murid community, demographically dominant in Marseille, underwent a reorganization, as leaders from the dominant families in Senegal arrived to rule over the local praying circle (dahira), previously dominated by rich tradesmen (Bava 2003b). These new arrivals coincided with a reorientation of Murid hierarchies and disciples towards a rigorous morality in response to the growing influence of puritan Islam's ideology coming from Saudi Arabia, both in Marseille and in Senegal.

The ever-present control paranoia of female behaviour depends also on another Marseille specificity: Senegalese migrants mostly settled downtown, thus sharing living and circulation space which allows tight social ties and more efficient control than in other French settings where migrants are scattered in different suburban zones (Poiret 1996). Migrants physical concentration in specific areas is the foundation for a strong community.

As accounts show, Senegalese women in Marseille firstly experimented with fluid sexual roles, a continuum between free women and wives (1920-1980) and subsequently, as immigrant numbers increased thanks to family reunions and puritan Islam ideology, they faced a polarization of social categories between wives and free women, or whores (1980-2000). Even if paradoxical, as Diattou's case shows, both men and women participate in promoting new restrictive norms for women's sexuality.

Secondly, representations of marital and non-marital sex vary enormously according to education, caste, geographic origin (urban/rural, big cities/small towns) and age. Migration appears as a social field in which women can use their sexuality strategically, juggling with changing social norms, in order to make their way, socially and economically. Yet paradoxically, migration may be both an escape and a trap when it comes to sexual agency. While some women may find a space of freedom in it (as Sokhna, who can freely live her sexual life and even uses it strategically, because she stepped out of the community and broke her ties with the family she left behind, and Awa early on), other harden the social constraints they embodied and auto-censure themselves in order to maintain their status (Diattou). Still, others find themselves marginalized from the community because of the sexual agency they have shown (Awa later on).

The third and concluding point: Senegalese women's sexual behaviour in migration is profoundly linked to time and place, as it is to cultural norms. Juggling with these norms, the changes in community moral orientations and individual interests, sexual behaviour becomes the mirror of larger social dynamics that cross-cut and orient migration. Thus, it appears as the crux where individual agency and social constraints come face to face and intersect in a highly exemplary way.

\section{References}

Babou, C. A. (2002). "Brotherhood Solidarity, Education and Migration: The role of the Dahiras among the Murid Muslim Community of New York". African Affairs, 101 (403): 151-170. https://doi.org/10.1093/afraf/101.403.151

Babou, C. A. (2008). "Migration and Cultural Change: Money, "Caste," Gender, and Social Status among Senegalese Female Hair Braiders in the United States". Africa Today, 55 (2): 3-22. https://doi.org/10.2979/AFT.2009.55.2.2

Balandier, G. (1984). "Le sexuel et le social: lecture anthropologique". Cahiers Internationaux de Sociologie, 76 (Janvier-Juin. Le sexuel): 5-19. 
Bava, S. (2003a). "De la "baraka" aux affaires: ethos économico-religieux et transnationalité chez les migrants sénégalais mourides". Revue Européenne des Migrations Internationales, 19 (2): 69-84. https://doi.org/10.4000/remi.454

Bava, S. (2003b). "Les Cheikh-s mourides itinérants et l'espace de la ziyâra à Marseille". Anthropologie et Société, 27 (1): 149-166. https://doi.org/10.7202/007006ar

Bertoncello, B. (2000). "Les marins africains de Marseille". Hommes et migrations, (1224): 22-27. https://doi.org/10.3406/homig.2000.3476

Bertoncello, B. and Bredeloup, S. (2004). Colporteurs africains à Marseille. Paris: Autrement.

Blanchard, M. (2007). "Migrantes sénégalaises "en solitaire" à Marseille. Des statuts ambigus entre marginalité et quête de reconnaissance". Diasporas. Histoire et sociétés, 11 111-122.

Blanchard, M. (2012). "Regard communautaire sur le parcours social et la sexualité des femmes sénégalaises "solitaires" à Marseille". SociologieS [En ligne], Dossier "Amours transi(t)s. Transactions sexuelles au prisme de la migration" (mis en ligne le 27 janvier 2012): URL: http://sociologies.revues.org/3863.

Buggenhagen, B. A. (2009). "Beyond Brotherhood: Gender, Religious Authority and the Global Circuits of Senegales Muridiyya". In: M. Diouf and M. Leichtman (eds) New Perspectives on Islam in Senegal. New York: Palgrave Macmillan. https://doi.org/10.1057/9780230618503_9

Coquery-Vidrovitch, C. (1994). Les Africaines. Histoire des femmes d'Äfrique Noire du XIXe au XXe siècle. Paris: Editions Desjonquères.

Diop, A. B. (1981). La société wolof. Les systèmes d'inégalité et de domination. Paris: Karthala.

Diop, A. B. (1985). La famille wolof. Paris: Karthala.

Ebin, V. (1993). "Les commerçants mourides a Marseille et a New York: regards sur les stratégies d'implantation". In: E. Grégoire and P. Labazée (eds) Grands commerçants d'Afrique de l'Ouest. Paris: Karthal-Orstrom.

Fainzang, S. and Journet, O. (1988). La femme de mon mari. Paris: L'Harmattan.

Foucault, M. (1976). Histoire de la sexualité. Tome I : La volonté de savoir. Paris Gallimard.

Fouquet, T. (2007a). "De la prostitution clandestine aux désirs de l'ailleurs : une « ethnographie de l'extraversion » à Dakar". Politique africaine, 3 (107): 102-123. https://doi.org/10.3917/polaf.107.0102

Fouquet, T. (2007b). "Imaginaires migratoires et expériences multiples de l'altérité : une dialectique actuelle du proche et du lointain". Autrepart, (41): 83-97. https://doi.org/10.3917/autr.041.0083

Hannaford, D. and Foley, E. E. (2015). "Negociating Love and Marriage in Contemporary Senegal; A Good Man Is Hard to Find". African Studies Review, 58 (02): 205-225. https://doi.org/10.1017/asr.2015.44

Héritier, F. (1996). Masculin/Féminin. La pensée de la différence. Paris: Odile Jacob.

Lévi-Strauss, C. (1949). Les structures élémentaires de la parenté. Paris: PUF.

Marie, A. (1997). "Introduction. L'individualisation africaine en questions". In: A. Marie (eds) L'Afrique des individus. Paris: Karthala.

Mathieu, N.-C. (eds) (1985). L'arraisonnement des femmes: essais en anthropologie des sexes. Paris: Editions de l'EHESS.

Meillassoux, C. (1975). Femmes, greniers et capitaux. Paris: Maspéro.

Morokvasic, M. (1983). "Women in migration: Beyond the reductionist outlook". In: A. Phizacklea (eds) One way ticket. Migration and female labour. London: Routledge.

Pedraza, S. (1991). "Women in migration: The social consequences of gender". Annual Review of Sociology, (17): 303-325. https://doi.org/10.1146/annurev.soc.17.1.303

Poiret, C. (1996). Familles africaines en France: Ethnicisation, ségrégation et communalisation. Paris: L'Harmattan.

Quiminal, C. (2000). "Construction des identités en situation migratoire : territoire des hommes, territoires des femmes". Autrepart, (14): 107-120.

Riccio, B. (2004). "Transnational Mouridism and the Afro-muslim Critique of Italy". Journal of Ethnic and Migration Studies, vol. 30 (n. 5): p. 929-944. https://doi.org/10.1080/1369183042000245624

Riccio, B. (2005). "Talkin ' about migration - some ethnographic notes on the ambivalent representation of migrants in contemporary Senegal". Stichproben. Wiener Zeitschrift für Afrikastudien, 8 99-118. 
Rubin, G. S. (1984). "Thinking Sex: Notes for a Radical Theory of the Politics of Sexuality". In: C. Vance (eds) Pleasure and Danger: exploring female sexuality. Boston and London: Routledge \& Kegan Paul.

Schmidt di Friedberg, O. (1994). Islam, solidarietà e lavoro. I muridi senegalesi in Italia. Torino: Fondazione Giovanni Agnelli.

Schmoll, C. (2005). "Pratiques spatiales transnationales et stratégies de mobilité des commerçantes tunisiennes". Revue Européenne des migrations internationales, 21 (1): 131-153. https://doi.org/10.4000/remi.2352

Tabet, P. (1985). "Fertilité naturelle, reproduction forcée". In: N.-C. Mathieu (eds) L'arraisonnement des femmes. Paris: Editions de l'EHESS.

Tabet, P. (2004). La grande arnaque : Sexualité des femmes et échange économico-sexuel Paris: L'Harmattan. 